\title{
ЕФЕКТИВНІ АТОМНІ ЗАРЯДИ КАНОНІЧНИХ 2'-ДЕЗОКСИРИБОНУКЛЕОТИДІВ ТА ЇХНЯ ЗАЛЕЖНІСТЬ ВІД КОНФОРМАЦІї
}

\author{
Т.Ю. НІКОЛАЄНКО, ${ }^{1}$ Л.А. БУЛАВІН, ${ }^{1}$ Д.М. ГОВОРУН ${ }^{1,2,3}$
}

${ }^{1}$ Київський національний університет ім. Тараса Шевченка, фізичний факультет (Вул. Володимирсъка, 64, Kиїв 01601; e-mail: tim_mail@ukr. net)

${ }^{2}$ Інститут молекулярної біології і генетики НАН України (Вул. Академіка Заболотного, 150, Київ 03680)

3 Науково-навчальний центр

“Державна ключова лабораторія молекулярної і клітинної біологї̈

Одержано середні за усіма можливими конформерами канонічних $2^{\prime}$-дезоксирибонуклеотидів (молекул $5^{\prime}$-дезоксицитидилової, 5'-тимідилової, 5'-дезоксиаденілової та 5'-дезоксигуанілової кислот) значення ефективних зарядів їхніх атомів та знайдено відповідні середньоквадратичні відхилення. Показано, що зазначені відхилення для атомів вуглецю можуть перевищувати середнє значення їхнього заряду. Проаналізовано можливість відтворення дипольного моменту конформерів за допомогою усереднених атомних зарядів і виявлено, що нехтування залежністю ефективних атомних зарядів від конформації молекули може приводити до похибок модуля дипольного моменту, більших за 100\%. Одержані результати можуть бути використані для вдосконалення електростатичних складових існуючих силових полів.

\section{1. Вступ}

Дослідження різноманітних фізичних властивостей фрагментів ДНК різної довжини та/або їхніх структурних ланок тривалий час було і залишається об'єктом пильної уваги дослідників [1-10]. Це зумовлено важливістю зазначених властивостей ДНК для розу-

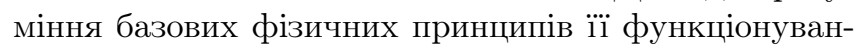
ня. Поряд із численними експериментальними методами - рентгено- та нейтронографії, коливальної та ЯМР-спектроскопї, розсіяння світла, дифракції електронів тощо - усе більшої ваги останнім часом набувають дослідження, виконані із застосуванням ме- тодів молекулярної динаміки (МД) (див., наприклад, [11-13] і посилання у них). Хоча метод МД є надзвичайно інформативним і вимагає значно менших порівняно із методами квантової хімії обчислювальних ресурсів, запорукою надійності одержуваних у МД дослідженнях результатів є коректність вибору конкретного "силового поля" - модельного потенціалу для визначення енергії взаємодій атомів біомолекули. Потенціальну енергію молекули, як правило, представляють у вигляді суми $[14,15]$ :

$U=U_{\text {chem }}+U_{\text {conf }}+U_{\mathrm{lr}}$,

де

$U_{\text {chem }}=\sum_{b} K_{b} \cdot\left(l_{b}-l_{0 b}\right)^{2}+\sum_{q} K_{q} \cdot\left(\theta_{q}-\theta_{0 q}\right)^{2}$

- енергія пружної деформації порівняно жорстких хімічних зв'язків (підсумовування проводяться за усіма довжинами $l_{b}$ хімічних зв'язків та величинами $\theta_{q}$ валентних кутів молекули; $l_{0 b}, \theta_{0 q}, K_{b}, K_{q}$ - сталі параметри),

$U_{\mathrm{conf}}=\sum_{s} K_{s} \cdot\left[1+\cos \left(n_{s} \cdot \varphi_{s}-\delta_{s}\right)\right]$

- "конформаційна" енергія, необхідна для взаємних поворотів сусідніх атомних груп навколо одинарних хімічних зв'язків (підсумовування проводяться за усі- 
ма торсійними кутами $\varphi_{s} ; n_{s}, \delta_{s}, K_{s}$ - сталі параметри), та

$U_{\mathrm{lr}}=\sum_{i, j}\left(\frac{q_{i} \cdot q_{j}}{r_{i j}}+\frac{A_{i j}}{\left(r_{i j}\right)^{m}}-\frac{C_{i j}}{\left(r_{i j}\right)^{n}}\right)$

- енергія далекодійних взаємодій (підсумовування проводиться за парами $(i, j)$ хімічно нез'єднаних атомів; $r_{i j}$ - міжатомні відстані, $A_{i j}, C_{i j}, m, n$ - сталі параметри, $q_{i}, q_{j}$ - ефективні атомні заряди). Неодмінною складовою енергії далекодійних взаємодій $U_{\mathrm{lr}} \in$ електростатична $\left(q_{i} q_{j} / r_{i j}\right)$, для моделювання якої кожному атому приписується певний ефективний заряд $q_{i}[14-16]$.

Разом із тим, відомо, що біомолекули характеризуються значною конформаційною ємністю: наприклад, кожен із чотирьох канонічних $2^{\prime}$ дезоксирибонуклеотидів (ДРН), елементарних (мономерних) ланок ДНК, може набувати 600-700 різних конформацій [17-20]. Зважаючи на те, що заряд атома у молекулі не є спостережуваною фізичною величиною, а вводиться на підставі тієї чи іншої моделі [21-27], можна очікувати залежності ефективних зарядів $q_{i}$ від конформації біомолекули (від кутів $\left.\varphi_{s}\right)$, адже незалежно від вибраної моделі значення цих зарядів визначають електронною конфігурацією, яка $є$ різною у різних конформерів. Таким чином, для коректного вирішення задач молекулярного моделювання методами МД важливо з'ясувати, чи обгрунтованим є використання фіксованих значень атомних зарядів під час побудови силових полів.

Метою даної роботи є на прикладі канонічних ДРН проаналізувати, якою мірою ефективні атомні заряди можуть залежати від конформації біомолекули, а також - визначити, наскільки точно усереднені за усіма конформерами біомолекул атомні заряди здатні відтворити дипольні моменти індивідуальних конформерів.

\section{2. Об'єкти і методи}

Для вирішення поставленої задачі було використано повні сімейства конформерів канонічних ізольованих ДРН (молекул 5'-дезоксицитидилової (5ДЦК), $5^{\prime}$-тимідилової (5TK), $5^{\prime}$-дезоксиаденілової (5ДАК) та $5^{\prime}$-дезоксигуанілової (5ДГК) кислот, див. рисунок), одержаних нами раніше [17-20] шляхом вичерпного квантово-механічного конформаційного аналізу, який виконували квантово-механічним методом функціонала густини (DFT) із використанням обміннокореляційного функціонала B3LYP $[29,30]$ і стандар- тного базисного набору 6-31G(d,p) [21]. На цьому ж рівні теорії визначали просторові розподіли густини заряду конформерів. Ефективні атомні заряди визначали окремо для кожної конформації кожного із досліджуваних ДРН методом Мерца-Коллмана [24, 25] без використання жодних додаткових умов щодо мультипольних моментів. Метод Мерца-Коллмана було вибрано через те, що з-поміж інших він призначений для якнайточнішого $[21,28]$ відтворення реального електростатичного потенціалу молекули системою точкових зарядів, центрованих на ядрах ㄲï атомів. За одержаними значеннями знаходили середній за усіма конформерами даного ДРН заряд кожного 3 його атомів та розраховували відповідні середньоквадратичні відхилення. Останні слугували мірою конформаційної чутливості ефективних атомних зарядів. Зважаючи на те, що найбільше практичне значення величини ефективних атомних зарядів мають для їхнього використання у молекулярному моделюванні методом МД, ці значення мають бути однаково придатними для будь-яких конформацій молекули. Відповідно, усі конформери розглядалися як рівноімовірні, а середні значення зарядів розраховували як середне арифметичне за усіма наявними конформерами (613 у 5ДЦК [17], 660 у 5TK [18], 726 у 5ДАК [19] та 745 у 5 ДГК [20]).

\section{3. Результати та їх обговорення}

\section{1. Заряди атомів цукрово-фосфатного остову}

Цукрово-фосфатним остовом ДРН називають спільну для усіх канонічних ДРН частину молекули цукровий залишок (атоми $\mathrm{C}_{1^{\prime}}, \mathrm{C}_{2^{\prime}}, \mathrm{C}_{3^{\prime}}, \mathrm{C}_{4^{\prime}}, \mathrm{C}_{5^{\prime}}, \mathrm{O}_{3^{\prime}}$, $\mathrm{O}_{4^{\prime}}$ та атоми водню, приєднані до них) та фосфатну групу (атоми $\mathrm{P}, \mathrm{O}_{\mathrm{P}}, \mathrm{O}_{\mathrm{P} 1}, \mathrm{O}_{\mathrm{P} 2}, \mathrm{H}_{\mathrm{P} 1}, \mathrm{H}_{\mathrm{P} 2}$ та $\mathrm{O}_{5^{\prime}}$; див. рисунок).

У табл. 1 наведено усереднені за усіма можливими конформерами ДРН значення ефективних зарядів атомів їхнього цукрово-фосфатного остову.

Одержані дані свідчать про те, що найбільш конформаційно чутливими є значення зарядів атомів вуглецю: їхні середньоквадратичні відхилення $\sigma_{q}$, віднесені до модуля заряду електрона $|e|$, становлять від 0,09 до 0,16 . Дещо менші значення $\sigma_{q} /|e|$ у атомів $\mathrm{O}_{5^{\prime}}$ i Р. Відзначимо, що різниця $\Delta_{q}=q_{\max }-q_{\min }$ максимального і мінімального значень зарядів кожного із атомів цукрово-фосфатного остову $\epsilon$, залежно від атома, від 4,8 до 8,4 разів більшою за величину відповідного середньоквадратичного відхилення $\sigma_{q}$. Най- 


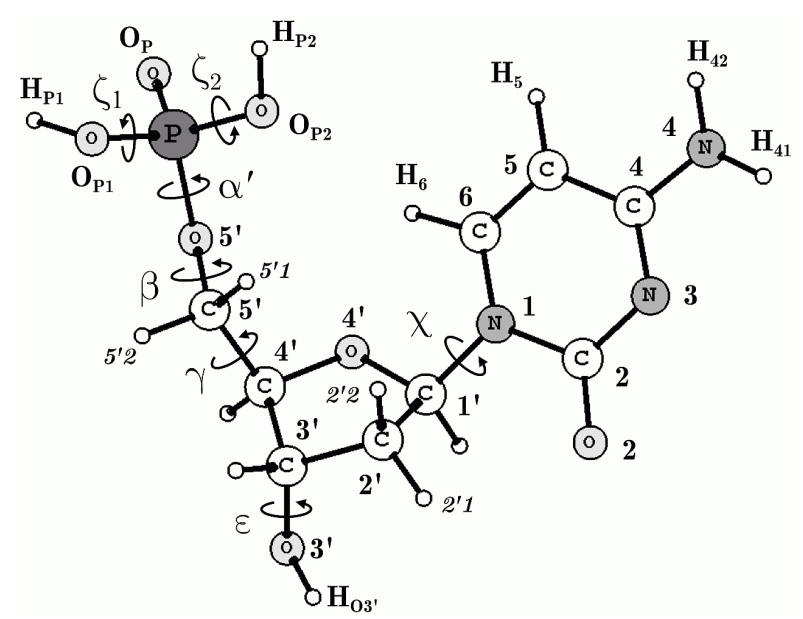

a)

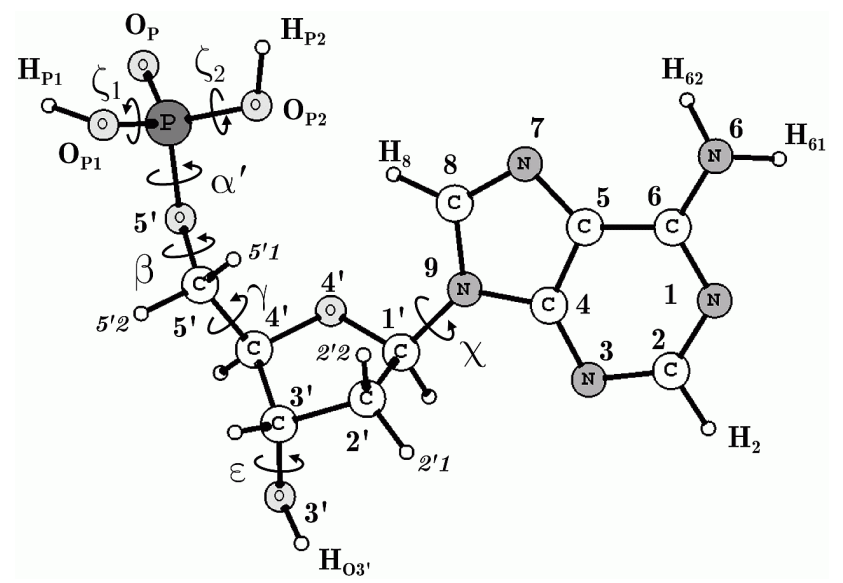

в)

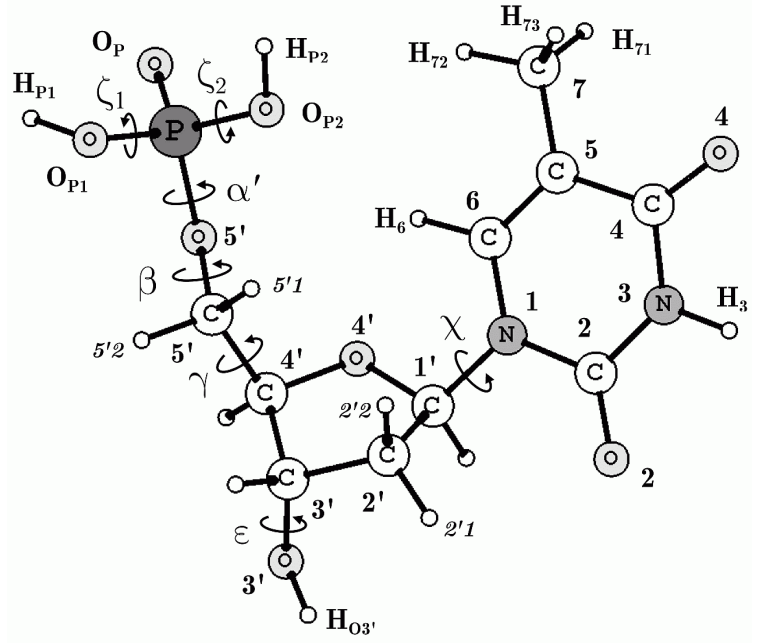

б)

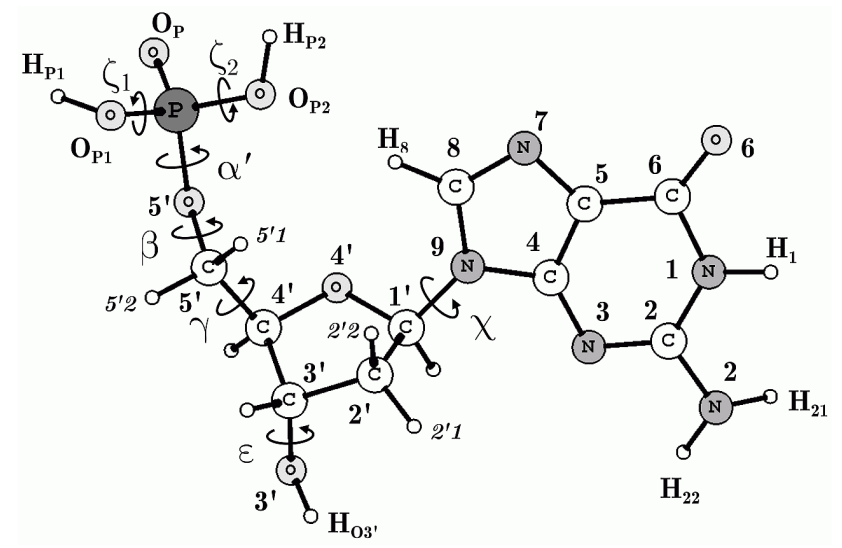

г)

Структури канонічних $2^{\prime}$-дезоксирибонуклеотидів - молекул $5^{\prime}$-дезоксицитидилової $(a), 5^{\prime}$-тимідилової (б), $5^{\prime}$-дезоксиаденілової (в) та 5'-дезоксигуанілової (2) кислот, позначення їхніх атомів та конформаційних параметрів

більшою у цукрово-фосфатного остову канонічних ДРН $\Delta_{q}$ є у атома $\mathrm{C}_{5^{\prime}}:(0,79-0,99) \cdot|e|$, а найменшою у атома $\mathrm{H}_{\mathrm{O} 3^{\prime}}:(0,12-0,13) \cdot|e|$.

\section{2. Заряди атомів нуклеотидних основ}

Нуклеотидні основи є "бітами" генетичної інформації, яку несе ДНК. Саме типом нуклеотидної основи відрізняються один від одного канонічні ДРН. Середні значення ефективних атомних зарядів та середньоквадратичні відхилення від них для атомів нуклео-

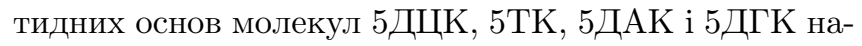
ведено у табл. 2, 3, 4 і 5 відповідно. У цих таблицях для порівняння наведено також значення $q_{\text {base }}$ eфективних атомних зарядів нуклеотидних основ, метильованих за глікозидним атомом азоту, знайдені у ро- боті [31] на тому самому рівні теорії DFT B3LYP/6$31 \mathrm{G}(\mathrm{d}, \mathrm{p})$, що і у даній роботі.

У пуринових нуклеотидних основ (аденіну та гуаніну) і цитозину виявлено, що найбільше (на $(0,14-$ $0,17) \cdot|e|)$ при заміні цукрово-фосфатного остову метильною групою змінюється заряд глікозидного атома азоту. На відміну від них, у тиміну найбільших змін (на $0,26|e|)$ зазнає заряд атома $C_{7}$, тоді як заряд глікозидного атома азоту змінюється менше (на $0,12|e|)$. Для усіх інших атомів нуклеотидних основ відмінність між середніми за усіма конформерами канонічних ДРН значеннями зарядів та значеннями зарядів нуклеотидних основ, метильованих за глікозидним атомом азоту, не перевищуе $0,1|e|$.

Найбільш чутливими до конформації ДРН у цитозину, тиміну та аденіну є заряд глікозидного атома 
Т а б ли ц я 1. Усереднені за усіма можливими конформаціями канонічних $\mathbf{2}^{\prime}$-дезоксирибонуклеотидів ${ }^{a}$ значення $\bar{q}$ ефективних зарядів атомів їх остову та середньоквадратичні відхилення $\sigma_{q}$ від них

\begin{tabular}{|c|c|c|c|c|c|c|c|c|}
\hline \multirow[t]{2}{*}{ Атом } & \multicolumn{4}{|c|}{$q /|e|$} & \multicolumn{4}{|c|}{$\sigma_{q} /|e|$} \\
\hline & 5ДЦК & $5 \mathrm{TK}$ & 5ДАК & 5ДГК & 5ДЦК & $5 \mathrm{TK}$ & 5ДАК & 5ДГК \\
\hline $\mathrm{H}_{1^{\prime}}$ & 0,05 & 0,06 & 0,07 & 0,06 & 0,03 & 0,03 & 0,03 & 0,03 \\
\hline $\mathrm{H}_{2^{\prime} 1}$ & 0,13 & 0,13 & 0,12 & 0,13 & 0,03 & 0,02 & 0,02 & 0,02 \\
\hline $\mathrm{H}_{2^{\prime} 2}$ & 0,12 & 0,13 & 0,12 & 0,11 & 0,03 & 0,03 & 0,03 & 0,04 \\
\hline $\mathrm{H}_{3^{\prime}}$ & 0,04 & 0,03 & 0,03 & 0,03 & 0,04 & 0,04 & 0,06 & 0,05 \\
\hline $\mathrm{H}_{O 3^{\prime}}$ & 0,40 & 0,40 & 0,40 & 0,40 & 0,02 & 0,02 & 0,02 & 0,02 \\
\hline $\mathrm{H}_{4^{\prime}}$ & 0,08 & 0,08 & 0,08 & 0,08 & 0,04 & 0,04 & 0,04 & 0,04 \\
\hline $\mathrm{H}_{5^{\prime} 1}$ & 0,10 & 0,10 & 0,08 & 0,09 & 0,04 & 0,03 & 0,04 & 0,04 \\
\hline $\mathrm{H}_{5^{\prime} 2}$ & 0,09 & 0,10 & 0,08 & 0,09 & 0,04 & 0,04 & 0,05 & 0,05 \\
\hline $\mathrm{H}_{P 1}$ & 0,43 & 0,43 & 0,43 & 0,43 & 0,03 & 0,02 & 0,03 & 0,03 \\
\hline $\mathrm{H}_{P 2}$ & 0,43 & 0,43 & 0,43 & 0,43 & 0,03 & 0,02 & 0,03 & 0,03 \\
\hline $\mathrm{O}_{3^{\prime}}$ & $-0,63$ & $-0,63$ & $-0,63$ & $-0,63$ & 0,03 & 0,03 & 0,03 & 0,03 \\
\hline $\mathrm{O}_{4^{\prime}}$ & $-0,41$ & $-0,40$ & $-0,40$ & $-0,40$ & 0,06 & 0,06 & 0,06 & 0,07 \\
\hline $\mathrm{O}_{5^{\prime}}$ & $-0,36$ & $-0,36$ & $-0,37$ & $-0,36$ & 0,07 & 0,08 & 0,08 & 0,08 \\
\hline $\mathrm{O}_{P}$ & $-0,58$ & $-0,58$ & $-0,58$ & $-0,58$ & 0,02 & 0,02 & 0,02 & 0,02 \\
\hline $\mathrm{O}_{P 1}$ & $-0,57$ & $-0,56$ & $-0,57$ & $-0,57$ & 0,04 & 0,03 & 0,04 & 0,04 \\
\hline $\mathrm{O}_{P 2}$ & $-0,56$ & $-0,56$ & $-0,57$ & $-0,57$ & 0,03 & 0,04 & 0,03 & 0,04 \\
\hline $\mathrm{C}_{1^{\prime}}$ & 0,37 & 0,36 & 0,35 & 0,35 & 0,11 & 0,12 & 0,13 & 0,16 \\
\hline $\mathrm{C}_{2^{\prime}}$ & $-0,36$ & $-0,39$ & $-0,35$ & $-0,35$ & 0,09 & 0,09 & 0,11 & 0,11 \\
\hline $\mathrm{C}_{3^{\prime}}$ & 0,32 & 0,35 & 0,33 & 0,33 & 0,11 & 0,11 & 0,13 & 0,12 \\
\hline $\mathrm{C}_{4^{\prime}}$ & 0,13 & 0,09 & 0,10 & 0,11 & 0,15 & 0,14 & 0,14 & 0,14 \\
\hline $\mathrm{C}_{5^{\prime}}$ & 0,00 & 0,00 & 0,05 & 0,03 & 0,13 & 0,13 & 0,15 & 0,15 \\
\hline $\mathrm{P}$ & 0,96 & 0,96 & 0,97 & 0,97 & 0,07 & 0,07 & 0,07 & 0,08 \\
\hline
\end{tabular}

${ }^{a}$ П р и м і т к а: Позначення молекул $2^{\prime}$-дезоксирибонуклеотидів: 5ДЦК, 5TK, 5ДАК, 5ДГК - 5'-дезоксицитидилова, 5'тимідилова, 5'-дезоксиаденілова та $5^{\prime}$-дезоксигуанілова кислоти відповідно.

азоту $\left(\sigma_{q} /|e|=(0,08-0,09)\right)$, тоді як у гуаніну - атома $N_{3}\left(\sigma_{q} /|e|=0,10\right)$, а заряд глікозидного атома азоту характеризується такою ж конформаційною чутливістю, як і у інших основ $\left(\sigma_{q} /|e|=0,08\right)$. Цікаво зазначити, що попри істотну відмінність середнього заряду атома $C_{7}$ тиміну у складі $5 \mathrm{TK}$ від його значення у метильованому тиміні, заряд цього атома чутливий до конформацій $5 \mathrm{TK}$ значно менше $\left(\sigma_{q} /|e|=0,03\right)$, ніж інші.

\section{3. Відтворення диполъних моментів конформерів}

Використовуючи наведені у табл. 1-5 усереднені за усіма конформаціями канонічних ДРН значення $\bar{q}_{i}$ ефективних атомних зарядів було досліджено, наскільки точно вони передають модуль і напрям дипольного моменту кожного із їхніх індивідуальних
Т а б л и ц я 2. Усереднені за усіма можливими конформаціями 5 ДЦК значення $\bar{q}$ ефективних зарядів атомів цитозину та середньоквадратичні відхилення $\sigma_{q}$ від них, віднесені до модуля заряду електрона ${ }^{a}$

\begin{tabular}{c|c|c|c|c|c|c}
\hline \multirow{2}{*}{ Величина } & \multicolumn{7}{|c}{ Атом } \\
\cline { 2 - 7 } & $\mathrm{N}_{1}$ & $\mathrm{C}_{2}$ & $\mathrm{~N}_{3}$ & $\mathrm{C}_{4}$ & $\mathrm{C}_{5}$ & $\mathrm{C}_{6}$ \\
\hline$q_{\text {base }}$ & $-0,19$ & 0,80 & $-0,76$ & 0,81 & $-0,54$ & 0,12 \\
$\bar{q}$ & $-0,33$ & 0,87 & $-0,78$ & 0,86 & $-0,62$ & 0,17 \\
$\sigma_{q}$ & 0,08 & 0,06 & 0,03 & 0,04 & 0,03 & 0,05 \\
\hline Величина & \multicolumn{7}{|c}{ Атом } \\
\cline { 2 - 7 } & $\mathrm{O}_{2}$ & $\mathrm{~N}_{4}$ & $\mathrm{H}_{41}$ & $\mathrm{H}_{42}$ & $\mathrm{H}_{5}$ & $\mathrm{H}_{6}$ \\
\hline$q_{\text {base }}$ & $-0,56$ & $-0,86$ & 0,39 & 0,37 & 0,18 & 0,12 \\
$\bar{q}$ & $-0,58$ & $-0,89$ & 0,41 & 0,39 & 0,22 & 0,13 \\
$\sigma_{q}$ & 0,02 & 0,03 & 0,02 & 0,01 & 0,01 & 0,02 \\
\hline
\end{tabular}

${ }^{a}$ П р и м і т к а: $q_{\text {base }}-$ ефективні атомні заряди 1-метилцитозину [31].

T а б л и ц я 3. Усереднені за усіма можливими конформаціями 5TK значення $\bar{q}$ ефективних зарядів атомів тиміну та середньоквадратичні відхилення $\sigma_{q}$ від них, віднесені до модуля заряду електрона ${ }^{a}$

\begin{tabular}{c|c|c|c|c|c|c|c}
\hline \multirow{2}{*}{ Величина } & \multicolumn{7}{|c}{ Атом } \\
\cline { 2 - 8 } & $\mathrm{N}_{1}$ & $\mathrm{C}_{2}$ & $\mathrm{~N}_{3}$ & $\mathrm{C}_{4}$ & $\mathrm{C}_{5}$ & $\mathrm{C}_{6}$ & $\mathrm{O}_{2}$ \\
\hline$q_{\text {base }}$ & $-0,10$ & 0,66 & $-0,64$ & 0,65 & $-0,11$ & $-0,10$ & $-0,53$ \\
$\bar{q}$ & $-0,22$ & 0,70 & $-0,65$ & 0,63 & $-0,02$ & $-0,11$ & $-0,54$ \\
$\sigma_{q}$ & 0,09 & 0,07 & 0,03 & 0,03 & 0,03 & 0,06 & 0,02 \\
\hline Величина & \multicolumn{7}{|c}{$\mathrm{Aтом}$} \\
\cline { 2 - 9 } & $\mathrm{H}_{3}$ & $\mathrm{O}_{4}$ & $\mathrm{H}_{6}$ & $\mathrm{C}_{7}$ & $\mathrm{H}_{71}$ & $\mathrm{H}_{72}$ & $\mathrm{H}_{73}$ \\
\hline$q_{\text {base }}$ & 0,37 & $-0,52$ & 0,16 & $-0,15$ & 0,05 & 0,07 & 0,07 \\
$\bar{q}$ & 0,38 & $-0,50$ & 0,18 & $-0,42$ & 0,13 & 0,14 & 0,14 \\
$\sigma_{q}$ & 0,01 & 0,01 & 0,04 & 0,03 & 0,01 & 0,01 & 0,01 \\
\hline
\end{tabular}

${ }^{a}$ П р и м і т к а: $q_{\text {base }}-$ ефективні атомні заряди 1-метилтиміну [31].

конформерів. Для цього у кожного із конформерів порівнювали вектор $\mathbf{d}_{q}=\sum_{i} \bar{q}_{i} \mathbf{R}_{i}$ дипольного моменту, розрахованого з використанням усереднених ефективних атомних зарядів $\bar{q}_{i}$, із вектором $\mathbf{d}_{\rho}=$ $\int \mathbf{r} \cdot \rho_{\text {mol }}(\mathbf{r}) \cdot d^{3} r$ дипольного моменту, визначеного за розподілом густини заряду молекули $\rho_{\mathrm{mol}}(\mathbf{r})$, визначеної за результатами квантово-механічних розрахунків. Відмінність знайденого $\mathbf{d}_{q}$ від $\mathbf{d}_{\rho}$ характеризували величиною $E_{d}=|| \mathbf{d}_{q}|-| \mathbf{d}_{\rho}|| /\left|\mathbf{d}_{\rho}\right|$ та кутом $\Theta$ між $\mathbf{d}_{q}$ та $\mathbf{d}_{\rho}$ (випадку рівності векторів $\mathbf{d}_{q}$ i $\mathbf{d}_{\rho}$ відповідали б значення $E_{d}=0$ та $\Theta=0^{\circ}$ ). Одержані значення величин $E_{d}$ та $\Theta$ наведено у табл. 6 . Із наведених даних випливає, що найточніше система сталих ефективних атомних зарядів передає дипольний момент у випадку молекули 5TK $\left(E_{d}<0,6\right)$, а найменш точно - у випадку 5ДАК. В останньому разі $E_{d}$ перевищує $100 \%$ у 11 конформерів із 726 можли- 
Т а б ли ц я 4. Усереднені за усіма можливими конформаціями 5 ДАК значення $\bar{q}$ ефективних зарядів атомів аденіну та середньоквадратичні відхилення $\sigma_{q}$ від них, віднесені до модуля заряду електрона ${ }^{a}$

\begin{tabular}{c|c|c|c|c|c|c|c}
\hline \multirow{2}{*}{ Величина } & \multicolumn{7}{|c}{ Атом } \\
\cline { 2 - 8 } & $\mathrm{N}_{1}$ & $\mathrm{C}_{2}$ & $\mathrm{~N}_{3}$ & $\mathrm{C}_{4}$ & $\mathrm{C}_{5}$ & $\mathrm{C}_{6}$ & $\mathrm{~N}_{7}$ \\
\hline$q_{\text {base }}$ & $-0,70$ & 0,53 & $-0,67$ & 0,46 & $-0,04$ & 0,65 & $-0,51$ \\
$\bar{q}$ & $-0,69$ & 0,48 & $-0,65$ & 0,48 & 0,00 & 0,64 & $-0,54$ \\
$\sigma_{q}$ & 0,03 & 0,05 & 0,07 & 0,06 & 0,05 & 0,04 & 0,02 \\
\hline Величина & \multicolumn{7}{|c}{ Атом } \\
\cline { 2 - 8 } & $\mathrm{C}_{8}$ & $\mathrm{~N}_{9}$ & $\mathrm{H}_{2}$ & $\mathrm{~N}_{6}$ & $\mathrm{H}_{61}$ & $\mathrm{H}_{62}$ & $\mathrm{H}_{8}$ \\
\hline \multirow{2}{*}{$q_{\text {base }}$} & 0,18 & $-0,10$ & 0,02 & $-0,79$ & 0,37 & 0,36 & 0,11 \\
$\bar{q}$ & 0,25 & $-0,26$ & 0,05 & $-0,82$ & 0,39 & 0,38 & 0,11 \\
$\sigma_{q}$ & 0,05 & 0,08 & 0,01 & 0,02 & 0,01 & 0,01 & 0,02 \\
\hline
\end{tabular}

${ }^{a}$ П р и м і т к a: $q_{\text {base }}$ - ефективні атомні заряди 9-метиладеніну [31].

Т а б л и я 5. Усереднені за усіма можливими конформаціями 5 ДГК значення $\bar{q}$ ефективних зарядів атомів гуаніну та середньоквадратичні відхилення $\sigma_{q}$ від них, віднесені до модуля заряду електрона ${ }^{a}$

\begin{tabular}{c|c|c|c|c|c|c|c|c}
\hline \multirow{2}{*}{ Величина } & \multicolumn{7}{|c}{ Атом } \\
\cline { 2 - 9 } & $\mathrm{N}_{1}$ & $\mathrm{C}_{2}$ & $\mathrm{~N}_{3}$ & $\mathrm{C}_{4}$ & $\mathrm{C}_{5}$ & $\mathrm{C}_{6}$ & $\mathrm{~N}_{7}$ & $\mathrm{C}_{8}$ \\
\hline$q_{\text {base }}$ & $-0,73$ & 0,79 & $-0,66$ & 0,35 & $-0,01$ & 0,64 & $-0,48$ & 0,14 \\
$\bar{q}$ & $-0,68$ & 0,73 & $-0,61$ & 0,32 & 0,07 & 0,57 & $-0,51$ & 0,20 \\
$\sigma_{q}$ & 0,06 & 0,08 & 0,10 & 0,08 & 0,05 & 0,04 & 0,02 & 0,05 \\
\hline Величина & \multicolumn{7}{|c|}{ Атом } \\
\cline { 2 - 10 } & $\mathrm{N}_{9}$ & $\mathrm{H}_{1}$ & $\mathrm{~N}_{2}$ & $\mathrm{H}_{21}$ & $\mathrm{H}_{22}$ & $\mathrm{O}_{6}$ & $\mathrm{H}_{8}$ & \\
\hline \multirow{2}{*}{$q_{\text {base }}$} & $-0,05$ & 0,40 & $-0,82$ & 0,36 & 0,36 & $-0,52$ & 0,11 & \\
$\bar{q}$ & $-0,20$ & 0,39 & $-0,82$ & 0,37 & 0,38 & $-0,49$ & 0,11 & \\
$\sigma_{q}$ & 0,08 & 0,01 & 0,04 & 0,01 & 0,02 & 0,01 & 0,02 & \\
\hline
\end{tabular}

${ }^{a}$ П р и м і т к a: $q_{\text {base }}-$ ефективні атомні заряди 9-метилгуаніну [31].

вих (найбільше $E_{d}$ у конформері 382 [18], в якому $\left|\mathbf{d}_{q}\right|=2,27 \mathrm{D}$, тоді як точне значення $\left.\left|\mathbf{d}_{\rho}\right|=0,46 D\right)$. Разом із тим, у більшості $(81 \%)$ конформерів 5 ДАК $E_{d}$ не перевищує $25 \%$.

Напрямок вектора дипольного моменту передається точніше. Навіть у випадку молекули 5ДАК, яка характеризується найбільшим значенням кута $\Theta, \Theta$ не перевищує $45^{\circ}$ у $98 \%$ конформерів. Однак, у двох конформерів цей кут становить $123,5^{\circ}$ (конформер 544 [18]) i 120, $8^{\circ}$ (конформер 344 [18]).

\section{4. Висновки}

Таким чином, встановлено, що найбільш конформаційно чутливими з-поміж усіх атомів цукрово-фосфатного остову канонічних 2 '-дезоксирибонуклеотидів є ефективні заряди атомів вуглецю. Присутність у
Т а б ли ц я 6. Статистичні характеристики точності відтворення дипольного моменту канонічних $2^{\prime}$ дезоксирибонуклеотидів системою точкових ефективних атомних зарядів ${ }^{a}$

\begin{tabular}{c|c|c|c|c}
\hline Молекула & $\left\langle E_{d}\right\rangle$ & $\max \left(E_{d}\right)$ & $\langle\Theta\rangle$ & $\max (\Theta)$ \\
\hline 5ДЦК & 0,09 & 0,98 & 9,5 & 54,4 \\
$5 \mathrm{TK}$ & 0,13 & 0,59 & 9,0 & 72,8 \\
5 ДАК & 0,21 & 3,95 & 14,8 & 123,5 \\
5ДГК & 0,09 & 0,74 & 7,5 & 35,5 \\
\hline
\end{tabular}

${ }^{a}$ П р и м і т к а: $E_{d}=|| \mathbf{d}_{q}|-| \mathbf{d}_{\rho}|| /\left|\mathbf{d}_{\rho}\right|-$ відносна різниця модулів векторів дипольного моменту $\mathbf{d}_{q}$, розрахованого 3 використанням усереднених атомних зарядів $\bar{q}_{i}$, та $\mathbf{d}_{\rho}$, визначеного за результатами квантово-механічних розрахунків; $\Theta-$ кут між векторами $\mathbf{d}_{q}$ i $\mathbf{d}_{\rho}$.

ДРН цукрово-фосфатного остову помітно впливає на ефективні заряди глікозидних атомів азоту нуклеотидних основ і атома $C_{7}$ тиміну. 3'ясовано, що усереднені ефективні атомні заряди для переважної більшості конформерів можуть слугувати надійним інструментом для якісного визначення електростатичного потенціалу молекули, але в окремих конформерах їхні значення є непридатними для кількісних розрахунків.

Одержані значення ефективних зарядів атомів канонічних 2 '-дезоксирибонуклеотидів можуть бути використані для удосконалення існуючих силових полів, що використовуються для дослідження біомолекул методами молекулярної динаміки, а також - для розрахунку електростатичного внеску в енергію взаємодії різних структурних ланок ДНК між собою (наприклад, нуклеотидної основи із цукрово-фосфатним остовом).

1. О.П. Чепинога, Нуклеиновые кислоты и их биологическая роль (Изд-во АН УССР, Киев, 1956).

2. E. Chargaff, Essays on Nucleic Acids (Elsevier, Amsterdam, 1963).

3. R.H. Sarma, Nucleic Acid Geometry and Dynamics (Pergamon Press, New York, 1980).

4. В. Зенгер, Принципы структурной организации нуклеиновых кислот (Мир, Москва, 1987).

5. Nucleic Acids in Chemistry and Biology, edited by G.M. Blackburn and M.J. Gait (IRL Press, Oxford, 1990).

6. R.L.P. Adams, J.T. Knowler, and D.P. Leader, The Biochemistry of the Nucleic Acids (Springer, New York, 1992).

7. R.R. Sinden, DNA Structure and Function (Academic Press, San Diego, 1994). 
8. V.A. Bloomfield, D.M. Crothers, and I. Tinoco, Nucleic Acids: Structures, Properties, and Functions (University Science Books, Sausalito, CA, 2000).

9. S. Neidle, Nucleic Acid Structure and Recognition (Oxford University Press, Oxford, 2002).

10. The Chemical Biology of Nucleic Acids, edited by G. Mayer (John Wiley and Sons, Chichester, 2011).

11. L. Yang and B.M. Pettitt, J. Phys. Chem. 100, 2564 (1996).

12. A. Perez, F.J. Luque, and M. Orozco, J. Am. Chem. Soc. 129, 14739 (2007).

13. A. Perez, F. Lankas, F.J. Luque, and M. Orozco, Nucleic Acids Res. 36, 2379 (2008).

14. A.D. Mackerell, J. Comput. Chem. 25, 1584 (2004).

15. J.W. Ponder and D.A. Case, Adv. Protein Chem. 66, 27 (2003).

16. J. Sponer, J. Leszczynski, and P. Hobza, J. Phys. Chem. 100, 5590 (1996).

17. Т.Ю. Ніколаєнко, Д.М. Говорун, Доповіді НАН України, 9, 173 (2010).

18. Т.Ю. Ніколаєнко, Л.А. Булавін, Д.М. Говорун, Український біохімічний журнал $\mathbf{8 2}$, № 6, 76 (2010).

19. Т.Ю. Ніколаєнко, Л.А. Булавін, Д.М. Говорун, Український біохімічний журнал 83,, № 4, 16 (2011).

20. Т.Ю. Ніколаєнко, Л.А. Булавін, Д.М. Говорун, Віopolym. Cell. 27, 291 (2011).

21. F. Jensen, Introduction to Computational Chemistry (Wiley, New York, 1999).

22. R.S. Mulliken, J. Chem. Phys. 23, 1833 (1955).

23. A.E. Reed, R.B. Weinstock, and F. Weinhold, J. Chem. Phys. 83, 735 (1985).

24. D.E. Williams, Rev. Comput. Chem. 2, 219 (1991).

25. U.C. Singh and P.A. Kollman, J. Comp. Chem. 5, 129 (1984).

26. J. Cioslowski, J. Am. Chem. Soc. 111, 8333 (1989).

27. R.F.W. Bader, P.M. Beddall, and P.E. Cade, J. Am. Chem. Soc. 93, 3095 (1971).

28. Т.Ю. Ніколаєнко, Л.А. Булавін, Д.М. Говорун, Ukr. Bioorg. Acta 9, 3 (2011).

29. P.J. Stephens, F.J. Devlin, C.F. Chabalowski, and M.J. Frisch, J. Phys. Chem. 98, 11623 (1994).

30. R.H. Hertwig and W. Koch, Chem. Phys. Lett. 268, 345 (1997).

31. G. Bakalarski, P. Grochowski, J. S. Kwiatkowski et al., Chem. Phys. 204, 301 (1996).

Одержано 11.11.11
ЭФФЕКТИВНЫЕ АТОМНЫЕ ЗАРЯДЫ КАНОНИЧЕСКИХ 2'-ДЕЗОКСИРИБОНУКЛЕОТИДОВ И ИХ ЗАВИСИМОСТЬ ОТ КОНФОРМАЦИИ

Т.Ю. Николаенко, Л.А. Булавин, Д.Н. Говорун

$\mathrm{P}$ е $з$ ю м е

Получены усредненные по всем возможным конформерам канонических $2^{\prime}$-дезоксирибонуклеотидов (молекул 5'дезоксицитидиловой, $5^{\prime}$-тимидиловой, $5^{\prime}$-дезоксиадениловой и $5^{\prime}$-дезоксигуаниловой кислот) значения эффективных зарядов их атомов и соответствующие среднеквадратические отклонения. Показано, что указанные отклонения для атомов углерода могут превышать среднее значение их заряда. Проанализирована возможность воспроизведения дипольного момента конформеров с помощью усредненных зарядов и установлено, что пренебрежение зависимостью эффективных атомных зарядов от конформации молекулы может приводить к погрешностям модуля дипольного момента, превышающих 100\%. Полученные результаты могут быть использованы для усовершенствования электростатических составляющих существующих силовых полей.

EFFECTIVE ATOMIC CHARGES OF CANONICAL 2'-DEOXYRIBONUCLEOTIDES AND THEIR CONFORMATIONAL DEPENDENCES

T.Yu. Nikolaienko ${ }^{1}$, L.A. Bulavin ${ }^{1}$, D.M. Hovorun ${ }^{1,2,3}$

${ }^{1}$ Taras Shevchenko National University of Kyiv, Faculty of Physics

(64, Volodymyrs'ka Str., Kyiv 01601, Ukraine; e-mail: tim_mail@ukr.net),

${ }^{2}$ Institute of Molecular Biology and Genetics,

Nat. Acad. of Sci. of Ukraine

(150, Academician Zabolotnyi Str., Kyiv 03143, Ukraine),

${ }^{3}$ Research and Education Center

"State Key Laboratory of Molecular and Cellular Biology" (150, Academician Zabolotnyi Str., Kyiv 03143, Ukraine)

$\mathrm{S} u \mathrm{~m}$ m a r y

Effective charges for the atoms of canonical $2^{\prime}$-deoxyribonucleotides (the molecules of $5^{\prime}$-deoxycytidylic, 5'-thymidylic, 5' deoxyadenylic, and $5^{\prime}$-deoxyguanylic acids) averaged over all of their possible conformers and the corresponding root-mean-square deviations have been obtained. It was shown that the charge deviations for carbon atoms can exceed the average values of the charge itself. A capability of reproducing the conformer dipole moments using averaged charges has been analyzed. It was found that the neglect of the dependence of effective atomic charges on the molecule conformation may result in the errors for the dipole moment magnitude exceeding 100\%. The results obtained can be used for the improvement of electrostatic components in existing force fields. 